\title{
On Teachers' College of media literacy education content system
}

\author{
Tang Yu \\ Chongqing City Management College, Chongqing 401331
}

\begin{abstract}
Key words: University teachers, Media literacy education, Content system, Construction method Abstract: Since the twenty-first century, with the rapid development of science and technology, more and more channels of information dissemination, information dissemination of the media is also increasing. Therefore, in this era background, how to use the information media in modern university teaching, make it better serve the teaching, is the modern university teachers need to focus on. In China's higher education, on improving the media literacy education of college teachers has begun to put on the agenda. This article mainly analyzes and discusses the necessity and concrete measures of the content system construction of the media literacy education of university teachers.
\end{abstract}

\section{Introduction}

The Media Literacy Research Center of the United States believes that personal media literacy can be reflected in the selection, comprehension, questioning, evaluation, creation and production, as well as the deliberate avoidance of the various kinds of information in the face of the media. Therefore, it can be said: media literacy is a public media have a correct and comprehensive understanding, and the use of media information processing ability or accomplishment. In modern society, people face a variety of information every day, there are many false, vulgar information, people can correctly distinguish the information, improve their own sense of judgment and decision-making, personal life, study and work is important influences.

\section{The Necessity of Media Literacy Education for College Teachers}

China's media literacy research started late, most of the domestic media literacy education institutions, the school did not open a special course. The public media literacy level is not high, media literacy education needs to be strengthened. According to some experts, because the propaganda of the media in China has a strong color of education, leading to the audience of media communication of information loss of basic judgment and questioning, people do not have the basic media literacy. This argument has a certain one-sideness, because through the survey found that college teachers as a senior intellectual class in the face of the media to disseminate a variety of information, generally have their own sense and understanding, reflecting a certain media literacy , but the Chinese media communication performance is still not optimistic.

\begin{tabular}{|c|c|c|c|c|}
\hline medium & TV & Magazine & Newspaper & Internet \\
\hline percent $(\%)$ & 53.21 & 49.54 & 48.62 & 82 \\
\hline
\end{tabular}

In this survey, more than half of the teachers in the face of media communication is the first to question the attitude of teachers on the media criticism of the attitude is more rational, and able to resist the spread of bad information. On the one hand, it shows that teachers' media literacy is worthy of affirmation, on the other hand, it embodies the drawbacks of the field of media communication in China. The media market is quite mixed in the media market. However, it is urgent for university teachers to meet the needs of media literacy in education and research under 
modern society by improving their own media literacy level in the face of complex media environment.

College teachers due to work needs, the media attention is also higher than the general public, media literacy is also high. However, the work pressure of university teachers, long working hours, the lack of systematic understanding of media literacy research. Mainly in the one hand, teachers bear the teaching and educating work, need to spend more time preparing lessons in the classroom to impart knowledge to students, but also to do a good job of teacher demonstration work; the other hand, the teachers themselves are very scientific research work heavy, need to spend a lot of time and effort to engage in scientific research, so that college teachers in the work under great pressure, no time to take into account the media literacy research.

\section{Constructing the Content System of Media Literacy Education for College Teachers}

At present, many countries have carried out in line with their own national conditions and social value orientation of media literacy education, such as the United Kingdom to carry out the "critical media literacy education"; Japan to open media access to information dissemination and media literacy education ", Emphasizing the training of people on the media dissemination of information creation and manufacturing capacity; Canada is focused on training people on the media content balance, media content and the relationship between the audience the ability to link the core lies in promoting people to form the basic critical ability. In the course of constructing the content system of media literacy education for teachers in China, we can draw lessons from these countries' experiences and methods, and combine the situation of our country, we need to do the following when we are facing the media literacy education for college teachers:

\subsection{The Characteristics of College Teachers}

As teachers of higher education, they have a high level of education and have a higher status in the society. Therefore, the task of the teachers is not only to undertake the teaching and educating work, but also to carry on the work. Difficult scientific research tasks. At the same time, the teachers' working conditions and working environment are superior, and they are able to master the media communication. These are the objective characteristics of college teachers.

\subsection{The Theoretical Basis of Constructing the Content System of Media Literacy Education for College Teachers}

As a part of humanistic education in colleges and universities, the media literacy education of university teachers is closely related to the purpose and theoretical basis of humanistic education. The theoretical basis of the media literacy education of university teachers is based on the theory of Marxism on the free and all-round development of human beings, on the basis of which the theory of constructivism and the theory of situational teaching are systematically supplemented.

\subsection{Content Design of Media Literacy Education for College Teachers}

\subsubsection{Cultivating Teachers' Media Consciousness}

Media literacy education for college teachers, we should first establish a correct sense of media literacy. Teachers in the field of vision and scope of activities should not be confined to the classroom and the laboratory, in peacetime life and work, the need to constantly pay attention to media dynamics, reading magazines reading newspapers reading habits, or listen to radio stations watching TV news, Habits, attention to various media and participation, access to media information and feedback. Such as teachers through the media access to relevant educational information, extract valuable information from which to enrich the content of personal teaching, improve the quality of education, but also entertainment personal life and work.

\subsubsection{Learn the basics of media}

After setting up basic media literacy, teachers should learn the basic knowledge of media. First 
of all, to understand the basic concepts of media, types and development process; clear the main functions of different media and the role of the media and the spread of the law and mode of operation; also understand the media laws and regulations, all media information on their dissemination should be the legal responsibility.

\section{Cultivate teachers' ability to use media}

\subsection{On the media have basic cognitive ability}

After the teachers have a basic understanding of the media, the main task of the next education is to develop their own ability to use the media. Teachers should have a basic understanding of the media, the media communication of information content, communication channels have a basic understanding. For example, the most exposed media in the college teachers are network platforms, radio stations, television programs, magazines and periodicals, newspapers and mobile phone applications, etc. These media communication environment and dissemination of content is different, teachers should have a basic understanding of this ability.

\subsection{Have the ability to question the media}

The questioning ability of the media can reflect a person's media literacy level. People are in the environment surrounded by all kinds of information, not everyone needs this information can have information on the ability to question. Especially in the Internet and mobile phone application software, the dissemination of information media, China's laws and regulations in this area is not perfect, the lack of information dissemination accountability mechanism, in addition to microblogging forwarding more than 500 will be convicted of punishment, other network platforms, the promulgation of specific penalties, which led to the network filled with all kinds of false, vulgar information. College teachers to receive information, the first question should be true and false, questioning, where the news comes from, why would such a report, the report is who, what is the ins and outs of the matter? Through questioning, we can reflect the level of media literacy of college teachers.

\subsection{On the media with critical and reflective ability}

Criticism and reflection of media are the core contents of media literacy education of college teachers. When receiving the media information, teachers can discern whether the information is true or false by questioning whether it is valuable or not, then criticize and rethink the information, keep a clear head and correct attitude before false and false information, and can not be the information is brainwashed or confused. At the same time, the criticism and reflection on the media information should be done independently by the individual, rather than by echoing with the crowd. The conclusion is that college teachers, when dealing with media information, have independent judgment on the content of information, and then carry out reflection, can improve the ability of individual media literacy.

\section{Conclusion:}

This paper mainly analyzes the content system construction of media literacy education of college teachers, which mainly discusses the necessity and the concrete construction method of media literacy education for college teachers. The purpose is to strengthen the media literacy level of college teachers, so that our higher education more three-dimensional, in line with the requirements of the development of the times.

\section{Acknowledgement}

This article is the result of 2015 Chongqing Education Science "12th Five-Year" planning topics.Project number:2015-ZJ-044 


\section{References:}

[1] Chang Wei Wei. Media literacy education and its role in the discussion. [J]. Journalism, 2015 (22).

[2] .Construction of the content system of media literacy education in colleges and universities. [J] .Higher Education, 2012 (12). 